\author{
REVIEW OF EUROPEAN AND COMPARATIVE LAW \\ VOLUME XL \\ YEAR 2020
}

\title{
THE EUROPEAN CITIZENS’ INITIATIVE REFORM: DOES IT MATTER?
}

\author{
Agnieszka Parol*
}

\begin{abstract}
The article aims to analyse the reform of the European Citizens' Initiative, which entered into force at the beginning of 2020. More specifically, the article focuses on the question whether a possible impact of the changes might be that of an increase in the number of legislative proposals, as so far, out of the seventy registered ECIs, only two resulted in legislative outcomes. De lege lata changes intend to popularize and to give effect to the ECI, especially through the strengthening of the position of this tool as an instrument of e-democracy and through the reinforcing of the principle of subsidiarity and the model of multi-level governance. The reform is a step in the right direction. However, it is rather unlikely that it could boost the ECI as an instrument of indirect legislative initiative, which so far has had little impact. Such a situation results from the fact that the ECI is treated as a subsidiary tool to the instruments of representative democracy, generally accepted as the basis of the system. This is also the effect of the way the quasi-monopoly of the European Commission in the area of legislative initiative is interpreted. In consequence, the effectiveness of the ECI is currently perceived through the prism of collecting over one million signatures and conducting noncommittal dialogue. Nevertheless, in the light of the above, it should be remembered that the most effective form of encouraging civil society to participate in political activity is to reinforce its agency. De lege ferenda, increasing the impact of the ECI on decision-making processes is not dependent on potential changes in primary or secondary law. The change of attitude will suffice. Indeed, an increased number
\end{abstract}

Ph.D., John Paul II Catholic University in Lublin, Faculty of Law, Canon Law and Administration, aparol@kul.pl, ORCID: 0000-0002-4354-680X. 
of legislative proposals stemming from the ECIs might be the result of a change in EU political culture and a greater respect for democratic rules.

Key words: European Citizens' Initiative, direct democracy

\section{INTRODUCTION}

The European Citizens' Initiative (ECI) is the most important instrument of participatory democracy ${ }^{1}$ in the EU and the only instrument of direct democracy at the supranational level. When applied, a group of at least one million citizens of the Member States of the EU may invite the European Commission to submit a proposal of a legal act. Introduced under the Treaty of Lisbon, the ECI constitutes an extension of the catalogue of political rights resulting from EU citizenship. It is a non-binding instrument and its consequences are dependent on the decisions of the European Commission, which enjoys a quasi-monopoly over legislative initiative.

The reform of the European Citizens' Initiative, which fully entered into force in early 2020, aims to improve the use of this instrument. In accordance with EU policy lines, the changes should considerably improve the effectiveness of the instrument, including a decrease in the number of registration rejections and an increase in the number of ECIs which would receive the required number of signatures. The reform also aims at reinforcing the principle of subsidiarity and multi-level governance by involving a broader groups of EU bodies or national parliaments in the evaluation of the ECIs. However, a question arises whether the reform aimed

In primary law, the basis of participatory democracy is laid down under Art. 11 TEU. Apart from the ECI, it also enumerates dialogue with representative associations and civil society and consultations with parties concerned. However, there are two fundamental differences between the ECI and the two above-mentioned forms. The first difference consists in the fact that the ECI is a bottom-up process, contrary to the above forms which are initiated and moderated by the Union's institutions (top-down approach). The second difference lies in the fact that the above instruments are merely tools for exchanging views, as opposed to the ECI, which may lead to a formal proposal of a legal act, after: Natassa Athanasiadou, The European Citizens' Initiative: Lost in Admissibility?, Maastricht Journal of European and Comparative Law 2(2019), 252. 
at improving the popularity and availability of the ECI will strengthen its impact on EU decision-making processes. As it seems, the most effective way to encourage the participation of the civil society in political activity is to increase the sense of people's agency.

The present effectiveness of the ECI as an instrument of indirect legislative initiative is, in fact, rather low. From among the over seventy ECIs, only five initiatives passed the required threshold of the number of signatures. What is more, those five ECIs ran up against very divergent attitudes. With regards to one of them, the European Commission refused to take any follow-up action. Another initiative was subject to merely soft actions, where the most visible result was the organization of a scientific conference. Only two ECIs resulted in the preparation and bringing forward of legislative proposals. However, they included only a selection of the requests put forward in the ECI's proposals. The fifth of the above-mentioned ECIs is currently awaiting a public hearing.

\section{THE EUROPEAN CITIZENS’ INITIATIVE IN PRIMARY LAW}

EU citizenship, established under the Treaty of Maastricht in the 1990s was aimed at strengthening the position of individuals in the EU system. It was to be achieved through the granting of political rights to each citizen, including the right to address EU institutions in writing. Those rights were initially restricted to petitions addressed to the European Parliament and complaints addressed to the European Ombudsman. At present, they include a wide catalogue of EU institutions and bodies and they are reinforced by the right to good administration, as laid down in the Charter of Fundamental Rights. The Treaty of Lisbon supplemented the list of political rights with the European Citizens' Initiative ${ }^{2}$. From the very beginning, it became one of the major and most widely discussed projects, an expression of the intention to bring the EU closer to its citizens, which was viewed as a significant tool of reinforcing the democratic legitimacy of

2 On historical development of the ECI and EU's attitude, see: Oana-Mariuca Petrescu, The European Citizens' Initiative: A Useful Instrument for Society and for Citizens?, Revista Chilena de Derecho 3(2014), 966. 
the Union and empowering its citizens ${ }^{3}$. De facto, it constitutes the only true innovation the Lisbon Treaty stipulates in the area of participatory democracy ${ }^{4}$. Simultaneously, it is the first instrument of direct democracy at the supranational level ${ }^{5}$. Apart from the referendum procedure, as foreseen in the legal systems of some Member States, the ECI provides EU citizens with an opportunity to have a direct impact on the decision-making processes in the Union (bottom-up approach). In a similar way to other political rights, it should contribute to a decrease in the democratic deficit and increase the participation of civil society in the governance of the Union.

In accordance with primary law ${ }^{6}$, EU citizens in the number of no less than one million, representinga significant number of the Member States ${ }^{7}$, may take the initiative of inviting the European Commission, within the framework of its powers, to submit any appropriate proposal on mat-

3 Jan Barcz, Inicjatywa obywatelska - aspekty prawne i instytucjonalne, Europejski Przegląd Sądowy 10(2011), 25.

4 Joana Mendes, Participation and the Role of Law after Lisbon: A Legal View on Article 11 TEU, Common Market Law Review 6(2011), 1849.

5 James Organ, Decommissioning Direct Democracy? A Critical Analysis of Commission Decision-Making on the Legal Admissibility of European Citizens Initiative Proposals, European Constitutional Law Review 10(2014), 422. The supranational character predisposes the ECI mechanism to having features distinct from those of a national level. Some authors indicate that the ECI is different from the national legislative initiatives in that it is not directed to a legislator but to the entity which merely has legislative initiative, which also points out to the originality of this instrument (Paweł Głogowski, Andreas Maurer, The European Citizens' Initiative - Chances, Constraints and Limits, Political Science Series, Institute for Advanced Studies, Vienna 2013, 8). It seems that submitting the ECI to the EC results primarily from the specificity of the principle of institutional balance and its reflection in the decision-making process.

6 Art. 11(4) Treaty on the European Union (O.J. C 202, 7.06.2016, p. 13, consolidated version); hereinafter referred to as TEU.

7 Taking into account the condition of minimal representation of particular Member States, which is estimated in a correlation to the number of representatives of a given Member State in the European Parliament (principle of degressive proportionality). The final minimal number of votes from a given Member State equals a product of the number 751 (maximum number of the members of the European Parliament) and the figure determining the number of mandates for a given Member State. See: Art. 3 Regulation (EU) 2019/788 of the European Parliament and of the Council of 17 April 2019 on the European citizens' initiative (O.J. L 130, 17.05.2019, p. 55), hereinafter referred to as regulation 2019/788. 
ters where citizens consider that a legal act of the Union is required for the purpose of implementing the Treaties ${ }^{8}$. In 2011, the European Parliament and the Council, at the request of the European Commission, adopted the first regulation ${ }^{9}$, which determined the rules and procedures of the application of the ECI. In entered into force a year later providing an opportunity to initiate the very first ECIs. Next, the legal frameworks with regard to the European Citizens' Initiative were complemented by an implementing regulation ${ }^{10}$. The legal acts enumerated above laid down a periodical procedure of reviewing and reporting ${ }^{11}$ on the functioning of the ECI, which resulted in the reform of the initiative ${ }^{12}$. The new regulation entered fully into force in January 2020.

In accordance with the Preamble to Regulation 2019/788 ${ }^{13}$, in order to achieve the objectives of the citizens' initiative, the procedures and conditions required for the European Citizens' Initiative should be effective, transparent, clear, simple, user-friendly, accessible for persons with disabilities and proportionate to the nature of this instrument. The very same Preamble points out, on the grounds of primary law ${ }^{14}$, that the European citizens' initiative should be considered in the context of other means by which citizens may bring certain issues to the attention of institutions of the Union and which consist notably of dialogue with representative associations and civil society, consultations with parties concerned, petitions

8 The European Commission rejects initiatives or partially rejects them if they manifestly fall outside the framework of the Commission's powers, if the initiative is manifestly abusive, frivolous or vexatious or if the initiative is manifestly contrary to the values of the Union, Art. 6(3) regulation 2019/788.

9 Regulation (EU) no 211/2011 of the European Parliament and of the Council of 16 February 2011 on the citizens' initiative (O.J. L 65, 11.03.2011, p. 1), hereinafter referred to as regulation $211 / 2011$.

10 Commission Implementing Regulation (EU) no 1179/2011 of 17 November 2011 laying down technical specifications for online collection systems pursuant to Regulation (EU) no 211/2011 of the European Parliament and of the Council on the citizens' initiative (O.J. L 301, 18.11.2011, p. 3).

11 Art. 22 regulation 211/2011.

12 Regulation 2019/788.

13 Preamble recital (6) regulation 2019/788.

14 Art. 11 TEU and art. 24 TFEU. 
and applications to the Ombudsman. Further, it states ${ }^{15}$ that the new solutions should strike a judicious balance between rights and obligations and should ensure that valid initiatives receive an appropriate examination and response by the Commission. However, what is meant by the "judicious balance between rights and obligations" has not been clarified.

\section{THE CURRENT APPLICATION OF THE INSTRUMENT OF THE EUROPEAN CITIZENS' INITIATIVE}

To date, 71 initiatives were registered, whereas 23 applications were rejected (a decisive majority in the period between April 2012 and March $2015)^{16}$. As of now, around 9 million signatures have been collected. Within the same time frame, eight citizens committees initiated procedure before the General Court against the decisions of the Commission ${ }^{17}$. Most of the cases concerned rejection to register the initiative; however, there were also cases regarding dissatisfaction as to the course of action followed by the Commission in the case of the already registered ECIs. Four appeals were brought against the judgments of the General Court to the Court of Justice $(\mathrm{CJEU})^{18}$. In the majority of cases both courts sup-

15 Preamble recital (6) regulation 2019/788.

16 https://europa.eu/citizens-initiative/home_pl [date of access: 12.01.2020].

17 Cases: Michael Efler et al. v. European Commission, case T-754/14, ECLI: EU: T: 2017: 323; HB et al. European Commission, case T-361/14, ECLI: EU: T: 2017: 252; Bruno Costantini et al. v. European Commission, case T-44/14, ECLI: EU: T: 2016: 223; Balázs-ÁrpádIzsák and Attila Dabis v. European Commission, case T-529/13, ECLI: EU: T: 2016: 282; Alexios Anagnostakis v. European Commission, case T-450/12, ECLI: EU: T: 2015: 739; Bürgerausschussfür die Bürgerinitiative Minority SafePack - one million signatures for diversity in Europe v. European Commission, case T-646/13, ECLI: EU: T: 2017: 59; Romania v. European Commission, case T391/17, ECLI: EU: T: 2019: 672; European Citizens' Initiative One of Us et al. v. European Commission, case T-561/14, ECLI: EU: T: 2018: 210.

18 Cases: Alexios Anagnostakis v. European Commission, case C-589/15, ECLI: EU: C: 2017: 663; Balázs-ÁrpádIzsák and Attila Dabis v. European Commission, case C-420/16, ECLI: EU: C: 2019: 177; Patrick Grégor Puppinck et al. v. European Commission, case C-418/18 P, ECLI: EU: C: 2019: 1113; Romania v. Commission, case C-899/19 $\mathrm{P}$ (ongoing). 
ported the stance of the European Commission ${ }^{19}$. From among all the initiatives only five met the condition of the required number of signatories, which in the opinion of the Commission meant that they were successful. The number of "successful" initiatives shows how exceptionally difficult and tiresome this process is ${ }^{20}$.

The first of the initiatives which collected over a million signatures ${ }^{21}$ was an initiative "Access to water and sanitation as a human right. Water is a public good, not a commodity" (Right2water). The citizens' committee in the said matter asked the European Commission to propose legislation implementing the human right to water and sanitation, in accordance with the guidelines by the United Nations, and promoting the provision of water and sanitation as essential public services for everyone ${ }^{22}$. Further, the committee indicated that EU law should obligate the governments of particular states to ensure and to provide all citizens with sufficient and clean drinking water and sanitation. The objectives of the initiative consisted in the following: 1 . The EU institutions and Member States should be obliged to ensure that all inhabitants enjoy the right to water and sanitation. 2. Water supply and management of water resources should not be subject to 'internal market rules' and that water services are excluded from liberalisation. 3. The EU increases its efforts to achieve universal access to water and sanitation. It was also one of the few ECIs which lived to see the launching of a legislative process as part of the follow-up activities. In 2015 the amendments to the framework directive on drinking water were adopted ${ }^{23}$, with a view to better monitoring of drinking water in

19 The Court twice annulled the decision of the EC on non-registering an initiative, cases T-754/14 and T-646/13. As of now, the CJEU only once questioned the stance of the EC by overruling the decision on non-registering an ECI, case C-420/16. Case C-899/19 P is still pending judgement.

20 Paweł Głogowski, European Citizens' Initiative in Central and Eastern European Countries - The Bumpy Road of Participatory Democracy in the EU, Studia Europejskie 1(2017), 190.

21 The initiative obtained 1659543 signatures.

22 https://ec.europa.eu/citizens-initiative/public/initiatives/successful/details/2012/ 000003 [date of access: 4.01.2020].

23 Proposal for a directive of the European Parliament and of the Council on the quality of water intended for human consumption (recast), COM(2017) 753. 
the whole of Europe, which entered into force on 28 October 2015. Three years later another stage of the changes to the above-mentioned directive was initiated. The undertaken actions do not fully meet the postulates of the ECI, but still constitute an important step towards the realization of the proposal by civil society.

The second of the initiatives was the proposal "One of us", which collected the largest number of signatories ${ }^{24}$. It shows that the number of the collected signatures is inherently connected with the subject of the initiative, which is a highly sensitive issue from the ideological perspective. As the subject of the ECI, the citizens' committee indicated the legal protection of human dignity, the right to life and integrity of every human being since conception, within the areas of EU competences. The committee indicated that the EU should end the financing of activities which presuppose the destruction of human embryos, in particular in the areas of research, development and public health. In concreto, the initiative proposed that three legal acts be changed in the following areas: financial regulations determining the spending of the EU budget ${ }^{25}$, financing of research $^{26}$ and cooperation for development ${ }^{27}$. In the communication ${ }^{28}$ adopted on 28 may 2014 the Commission explains that it had resolved not to put forward a legislative proposal in that matter, as it had only recently been the subject of debate in the Member States and European Parliament, which determined the course of action. Apart from that, the Commission deemed the existing frameworks of financing as agreed on and considered proper by the Member States and the European Parliament. Such a stance

241721626 signatures.

25 Council Regulation (EC, Euratom) no 1605/2002 of 25 June 2002 on the Financial Regulation applicable to the general budget of the European Communities (O.J. L 248, 16.09.2002, p. 1).

26 Proposal for a regulation of the European Parliament and of the Council establishing Horizon 2020 - The Framework Programme for Research and Innovation (2014-2020), $\operatorname{COM}(2011) 809$.

27 Regulation (EC) no 1905/2006 of the European Parliament and of the Council of 18 December 2006 establishing a financing instrument for development cooperation (O.J. L 378, 27.12.2006, p. 41).

$28 \operatorname{COM}(2014) 355$. 
resulted in a complaintbrought before the General Court ${ }^{29}$. After it had been rejected, an appeal was directed at the Court of Justice ${ }^{30}$. Both instances supported the stance of the European Commission.

The third of the initiatives "Stop vivisection" concerned a proposal to create European legislative norms aimed at phasing out experiments on animals ${ }^{31}$. The authors of the initiative took as their main aim to apply to the European Commission to abrogate Directive 2010/63/EU on the protection of animals for scientific purposes and to put forward a paradigm shiftthat would prohibit experiments on animals, introducing in its place a compulsory use of data directly relevant to human species in biomedical and toxicological research. In response, the European Commission indicated that the applicability of Directive 2010/63/EU was necessary for maintaining animal welfare and that the Commission would undertake initiatives for appropriate and full implementation of the Directive in the Member States. The Commission pointed out a number of soft measures undertaken for this purpose, whereas still the most prominent one was the organization of a scientific conference ${ }^{32}$. Such approach met with disapproval of the organizers of the initiative who filed a complaint against the actions of the European Commission with the Ombudsman ${ }^{33}$ on the, in their opinion, inadequatereaction of the $\mathrm{EC}$ regarding the issue in question. In the end, the complaint was rejected.

The fourth initiative concerned the prohibition of the use of glyphosate and protection of people and the environment from toxic pesticides ("Stopglyphosate") ${ }^{34}$. The organizational committee asked the European Commission to propose to the Member States that they consider a ban on the use of glyphosate, reform the pesticide approval procedure and set EU-wide mandatory reduction targets for pesticide use. The citizens'

29 Case T561/14.

30 Case C-418/18.

31 The initiative collected 1173130 signatures.

32 https://ec.europa.eu/citizens-initiative/public/initiatives/successful/details/follow-up/2012/000007/pl?lg=pl [date of access: 4.01.2020]; https://ec.europa.eu/environment/chemicals/lab_animals/3r/pdf/scientific_conference/non_animal_approaches_conference_report.pdf [date of access: 4.01.2020].

33 https://www.ombudsman.europa.eu/en/decision/en/78182.

34 The initiative collected 1070865 signatures. 
committee identified three particular objectives of the initiative. The first one was to ban glyphosate-based herbicides, exposure to which has been linked to cancer in humans, and has led to ecosystem degradation. The second objective was to ensure that the scientific evaluation of pesticides for EU regulatory approval is based only on published studies, which are commissioned by competent public authorities instead of the pesticide industry. The third aim involved setting EU-wide mandatory reduction targets for pesticide use, with a view to achieving a pesticide-free future. As for the first objective, the Commission in its communication undermined the findings of the organizers, pointing out to the lack of scientific and legal grounds for justifying a ban on the use of glyphosate. By doing so, the Commission stated that it would not put forward a legislative proposal in that regard. Similarly, with regard to the third objective, the Commission determined that the existing regulation in the area of using pesticides was sufficient and stated that it would increase its commitment to implement the Directive on reduction measures in the use of pesticides. On the other hand, in the area of the second objective, the Commission decided to put forward a legislative proposal ${ }^{35}$, which resulted in the adoption of a new regulation ${ }^{36}$ in June 2019.

The fifth of the initiatives "Minority SafePack, one million signatures for diversity in Europe" 37 , calls on the European Union to improve the protection of persons belonging to national and linguistic minorities and to strengthen cultural and linguistic diversity within the Union. The particular aims of the initiative have been further specified by the European Commission ${ }^{38}$. The initiative collected 1128385 signatures, thus ex-

35 Proposal for a Regulation of the European Parliament and of the Council on the transparency and sustainability of EU risk assessment in the food chain (...), COM (2018) 179.

36 Regulation (EU) 2019/1381 of the European Parliament and of the Council of 20 June 2019 on the transparency and sustainability of the EU risk assessment in the food chain (...), (O.J. L 231, 6.09.2019, p. 1).

37 https://europa.eu/citizens-initiative/initiatives/details/2017/000004_pl [date of access: 12.01.2020].

38 Commission Decision (EU) 2017/652 of 29 March 2017 on the proposed citizens' initiative entitled "Minority SafePack — one million signatures for diversity in Europe", (O.J. L 92, 6.04.2017, p. 100). 
ceeding the required threshold of one million signatures. At present, it has been submitted to the European Commission and is waiting for the date of the public hearing to be announced ${ }^{39}$.

Summing up, as of now only two of the initiatives have been realized in accordance with their potential, i.e. resulted in putting forward legislative proposals. Just to remind, it occurred in the period of 8 years of the functioning of the instrument, with 71 registered initiatives and further 23 rejected by the EC. On the basis of the above statistics, it could be claimed, after one of the authors, that this instrument had hardly any impact on the strengthening of democracy and reducing its deficiency at the level of the $\mathrm{EU}^{40}$. However, it was to be expected ${ }^{41}$.

\section{THE IMPACT OF THE CITIZENS’ INITIATIVE ON EU LEGISLATION}

Despite the unfavourable statics, the current Regulation follows the previous one in that the ECI contributes to the strengthening of the democratic functioning of the Union through the participation of its citizens in the democratic and political life of the Union. As a tool for promoting debate, its task is to facilitate participation of the largest number of citizens in the democratic decision-making of the Union. In as much as the Preamble does not have a normative value, it still explains the philosophy behind this legal act ${ }^{42}$. As confirmed by the CJEU, the aim of the ECI is to empower the Union's citizens with the right to apply to the European Commission, which is comparable to the right of indirect legislative initiative of the European Parliament and of the Council ${ }^{43}$.

39 https://europa.eu/citizens-initiative/news_pl [date of access: 12.10.2020].

40 Tomasz Kubin, Znaczenie europejskiej inicjatywy obywatelskiej w kontekście deficytu demokracji w Unii Europejskiej, Politeja 54(2018), 117.

41 After: Victor Cuesta-López, "A Preliminary Approach to the Regulation on European Citizens' Initiative from Comparative Constitutional Law”, Bruges Political Research Papers / Cahiers de recherche politique de Bruges no 24 / February 2012, 8, https://www. coleurope.eu [date of access: 13.12.2019].

42 See: G. Schwarze v. Einfuhr- und VorratsstellefürGetreide und Futtermittel, case 16/65, ECLI:EU:C:1965:117.

43 Paragraph 61 case C-418/18 P. 
On the one hand, The European Commission itself describes the ECI as an instrument reinforcing the democratic mandate in the EU through an increased involvement and participation of citizens, emphasizing it as one of its priorities ${ }^{44}$. Moreover, the Commission also points out that the main objective of the ECI is to promote public debate on European issues, even if a given initiative does not finally fall within the framework of the legal powers of the Commission ${ }^{45}$. It observes that by directly involving citizens and allowing them to put forward their ideas on issues that matter to them, the ECI contributes an additional value to the EU law-making process and contributes to bringing citizens closer to the Union ${ }^{46}$. On the other hand, simultaneously defending its prerogatives, the Commission indicates that the ECI is an agenda-setting initiative. Thus the ECI does not have an impact on the right of the Commission to propose its own initiatives, but it obliges the Commission as a college to give serious consideration to the requests made by citizens' initiatives ${ }^{47}$. The General Court describes the citizens' initiative in the same vein in the ruling with regard to the initiative "One of us", in which it observes that within "exercising its powers of legislative initiative, the Commission must be allowed broad discretion, in so far as, through that exercise, it is called upon (...) to promote the general interest of the Union by carrying out, possibly, the difficult task of reconciling divergent interests. It follows that the Commission must be allowed broad discretion in deciding whether or not to take an action following an ECI"48.

The CJEU points out that the purpose of the ECI is to "invite" the Commission to submit an appropriate proposal for the purpose of implementing the Treaties, but it does not impose an obligation for this

44 Jean-Claude Juncker, A New Start for Europe: My Agenda for Jobs, Growth, Fairness and Democratic Change, https://ec.europa.eu/commission/presscorner/detail/en/ SPEECH_14_546 [date of access: 12.12.2019].

45 Proposal for a Regulation of the European Parliament and of the Council on the citizens' initiative, COM(2010)119, hereafter as the 2010 ECI proposal.

46 Report on the application of Regulation (EU) no 211/2011 on the citizens' initiative, Brussels, 28.03.2018, COM(2018)157, hereinafter as the ECI second report, 16.

472010 ECI proposal.

48 Paragraph 169 case T561/14. 
institution to undertake specific actions ${ }^{49}$. Further, the CJEU observes that when the Commission receives an ECI, it is to set out the action that it intends to take and the reasons for taking or not taking action, which confirms that the submission by the Commission of a proposal for an EU act in response to an ECI is optional. However, the power of legislative initiative of the Commission expresses the principle of institutional balance, characteristic of the institutional structure of the European Union, which means that each of the institutions must exercise its powers with due regard for the powers of the other institutions ${ }^{50}$. This quasi-monopoly in the area of legislative initiative conferred on the Commission by the Treaties is justified by the function performed by the Commission ${ }^{51}$. The obligation to submit a legislative proposal would be incompatiblewith the discretion enjoyed by the Commission in its task of promoting the general interest of the Union and taking appropriate initiatives to that end, and with the general obligation incumbent on the Commission to be completely independent in the exercise of its power of initiative ${ }^{52}$.

The Court of Justice observes that the fact that the Commission is not obliged to take action in response to an ECI does not mean that such an initiative lacks effectiveness ${ }^{53}$. The CJEU also emphasizes that an ECI meeting legal requirements imposes on the Commission a certain number of obligations as laid down in secondary law ${ }^{54}$. Under the law which provided grounds for the ruling, they said obligations included publication in the registry of the initiatives. Moreover, if an ECI obtained the required number of signatures, the EC had an obligation to receive the organizers at the most appropriate level and to present its legal and political conclusions in the form of a communication, together with a justification for taking or not taking action. As was emphasized by Advocate General ${ }^{55}$ and

49 Paragraph 57 case C-418/18 P.

50 Paragraph 60 case C-418/18 P.

51 Paragraphs 110 and 111 case T-561/14.

52 Paragraph 62 case C-418/18 P.

53 Paragraph 64-66 case C-418/18 P.

54 Regulation 211/2011.

55 Point 78 Opinion of Advocate General Michał Bobek presented on 29 July 2019, ECLI:EU:C:2019:640. 
further supported by the CJEU ${ }^{56}$, the particular added value of the ECI mechanism resides not in certainty of outcome, but in the possibilities and opportunities that it creates for Union citizens to initiate debate on policy within the EU institutions without having to wait for the commencement of a legislative procedure.

The Court of Justice also observes that the effectiveness of the initiative is based on the interpretation of the representative democracy and participatory democracy in primary law ${ }^{57}$. Thus, the CJEU points out that primary $l a w^{58}$ lays down that the functioning of the Union is to be based on representative democracy, which gives concrete expression to democracy as a value ${ }^{59}$. On the other hand, the system of representative democracy is complemented by such instruments as the ECI mechanism ${ }^{60}$. The instruments of participatory democracy ${ }^{61}$ are therefore subsidiary with regard to the system shaped by the mechanisms of representative democracy.

To sum up, in the opinion of the CJEU and the European Commission, almost all ECIs are effective. Furthermore, on the website of the ECI, the Commission refers to all the initiatives which exceeded the required number of one million signatures as successful ones ${ }^{62}$. Such an approach can also be seen in the documents of the Commission. Indeed, the focus on the very debate initiated by the ECI and not on its real impact on the decision-making processes allows for such a high assessment of the effectiveness of the mechanism in question. However, if the focus is shifted to the actual application of the ECI as an instrument of indirect legislative initiative, the very commencement of a discussion seems to be hardly satisfactory. The experience of over 60 initiatives which had not obtained the required number of signatures confirms the fact that collecting support from voters is a tedious and difficult task. It also points out to the scale of interest that a given citizens' committee should evoke and the amount

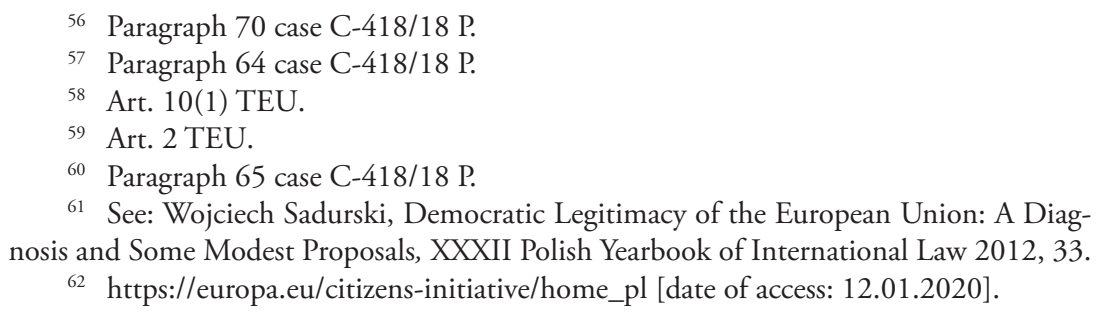

61 See: Wojciech Sadurski, Democratic Legitimacy of the European Union: A Diagnosis and Some Modest Proposals, XXXII Polish Yearbook of International Law 2012, 33. 62 https://europa.eu/citizens-initiative/home_pl [date of access: 12.01.2020]. 
of work that must be put in the signature collection process. Indeed, it is a huge success on the side of the organizers that an initiated public debate and dialogue carried out within civil society gathered such a large group of interested parties. Therefore, if it is an extraordinary event, it would naturally require a special interest from the side of the European Commission. A balance should be struck between full subjugation to the demands expressed in the initiatives and ignoring them completely ${ }^{63}$. It is especially important in the light of the fact that currently what could be observed is a mismatch between, on the one hand, the expectations of EU citizens from the ECI and, on the other hand, the ECI's present capacity to lead to legislative output ${ }^{64}$. It seems that in an organization founded on such a value as democracy and for the sake of respecting the organizers of the ECI and its signatories, a dialogue with civil society should result in relevant outcomes, including precisely legislative proposals. The stance of the European Commission regarding the initiatives which have been completed should at least create an impression that the voice of a million citizens was treated in all seriousness.

Undoubtedly, a serious treatment of the Union's citizens would mean that various ECIs would result in legislative action. Such an outcome would not necessarily have to transpire from the letter of the law, but from the change of the Union's political culture and its values. Indeed, in accordance with primary law ${ }^{65}$, one of the Union's values is precisely democracy, and not a representative model of democracy. With regard to the political culture even before the establishment of the ECI, the desire to enhance EU legitimacy has in the past been tempered, often severely, by the desire to get things done without participatory input, or at the very least without any

63 Anna Śledzińska-Simon, Obywatelstwo Unii Europejskiej jako demos, czyli fiasko demokratycznego telos?, In: Ochrona praw obywatelek i obywateli Unii Europejskiej. 20 lat - osiągnięcia i wyzwania na przyszłość, Adam Bodnar, Grażyna Baranowska, Aleksandra Gliszczyńska-Grabias, ed., Warszawa: Wolters Kluwer, 2015, 66.

${ }^{64}$ Anastasia Karatzia, The European Citizens' Initiative and the EU Institutional Balance: On Realism and the Possibilities of Affecting EU lawmaking, Common Market Law Review 1(2017), 177.

65 The above-mentioned Art. 2 TEU. 
binding obligation to engage in such process ${ }^{66}$. Perhaps the ECI is the instrument which should not be merely treated by the European Commission as an "invitation" to put forward a proposal of a legal act, but as one that is hard to be refused or at least one that should be seriously considered.

\section{THE REFORM OF THE EUROPEAN CITIZENS' INITIATIVE}

The current reform was preceded by a number of activities of a non-legislative character. In particular, the Commission ${ }^{67}$ : provided free hosting servers for the purposes of the systems established by the organizers for collecting declarations online; intensified counselling and support for (potential) organizers in the area of communicative activities; ensured that the systems for collecting declarations online to be used by the organizers are fully operational and accessible; and took a decision on a partial registration of the initiatives. Especially the activity in the latter area resulted in a significant decrease in the percentage of the initiatives not accepted for registration ${ }^{68}$. However, according to the EC, those improvements are not sufficient to realize the full potential of the $\mathrm{ECI}^{69}$. By engaging the instruments facilitating the establishment of a constructive social dialogue, in particular the REFIT platform ${ }^{70}$, and by making an ex post assessment, the Commission pointed out to three areas requiring legislative actions ${ }^{71}$.

${ }^{66}$ Paul Craig, The Lisbon Treaty. Law, Politics, and Treaty Reform, UOP Oxford 2010, 77.

67 II Report, 3.

68 Only 2 initiatives out of the proposed 17 submitted since April 2015 were rejected, in contrast to 20 rejected out of 51 in the period from April 2012 to March 2015.

69 Proposal for a regulation of the European Parliament and of the Council on the European citizens' initiative, $\operatorname{COM}(2017) 482$, 3, hereinafter as the 2017 ECI proposal.

${ }^{70} \mathrm{https} / /$ ec.europa.eu/info/files/refit-platform-recommendations-european-citizen-initiative_en [date of access: 4.01.2020]. See also: "Campaign for a citizens-friendly European Citizens' Initiative”, http://www.citizens-initiative.eu/.

712017 ECI proposal, 6. The proposal did not take into account the postulates such as the lowering of the number of the Member States, whose citizens support the initiative from seven to five, or the extension of the time for the collection of signatures to 24 months, see: Anna Śledzińska-Simon, Obywatelstwo Unii Europejskiej jako demos, czyli fiasko demokratycznego telos?, 65. 
The first area concerned the stage of registration, in particular a high rate of refusals to register the proposed citizens' initiatives. The second area referred to the stage of collecting declarations of support. The European Commission associated the complexity of the process of obtaining declarations with a low rate of initiatives ending in success. Activities undertaken in the third area were directly addressed at the problem of a low number of initiatives which gathered a million signatures and at the limited impact of citizens' initiatives on the legislative procedure. Irrespective of the identified stages, a common denominator indicated by the Commission is the acknowledgement that the existing regulations are complex and constitute a burden for the organizers of the European Citizens' Initiative, signatories and competent bodies of the Member States.

In accordance with the stance of the European Commission, the purpose of the reforms was to improve the functioning of the European Citizens' Initiative by solving the problem of shortcomings identified over the course of the last years ${ }^{72}$. The changes were focused on the following points: firstly, onmaking the European Citizens' Initiative more accessible, less burdensome and easier to operate by both the organizers and the supporters and secondly, on the full realization of the ECI's potential as a tool for promoting debate and participation at the European level, including the participation of young people, and on bringing the Union closer to its citizens.

Finally, among the elements of the applied reform one may distinguish those which: 1) propagate and facilitate the use of the ECI, especially through 2) the strengthening of the position of the ECI as an instrument of e-democracy and 3) broaden the scope of participation of other institutions and bodies, which uphold and ensure respect for the principle of subsidiarity and exercise the model of multi-level governance.

\subsection{Promoting best practices and facilitating access to the European Citizens' Initiative}

The European Commission has made a few significant changes which should have a positive impact on the organizational process of the initiative. Most importantly, the Commission agreed to consider a legal en-

722017 ECI proposal, 3. 
tity ${ }^{73}$ created in accordance with the national law of a Member Stateas the organizers of the initiative. This is intended, among others, to facilitate the possibility of gathering financial means to support particular ECIs and improve the effectiveness of contacts with the national institutions and public bodies.

The rules of registration have also been changed. Currently, a group of organizers has a possibility to make amendments to the initiative if it does not fulfil the criteria laid down in the current regulation and the EC may also register an initiative partially. The EC allows for the process of registration to have two stages ${ }^{74}$. The second stage of registration takes place when, in the opinion of the Commission, the initiative manifestly falls outside the framework of the Commission's powers to submit a proposal for a legal act of the Union ${ }^{75}$. The group of organizers has then two months to either submit amendments to the initiative in order to take into account the Commission's assessment or maintain, or withdraw, the initial initiative. If, after making amendments, the Commission still decides that the initiative falls outside its powers, it may be registered partially. This change in approach, so far applied without a direct legal basis, has already caused a significant decrease in the number of rejected initiatives.

The new solution also puts into practice a number of postulates of the organizers of the initiative with regard to the process of collecting declarations of support. At present, the organizers of the ECI set the start date of the collection period being limited only by the six-month period from the registration of the initiative. Such flexibility, allowing the group of organizers of the initiative ampletime for preparing for the whole process, should have a positive impact on the number of collected signatures.

In order to increase the catalogue of signatories, the minimum age for supporting an initiative was lowered to 16 years. EU institutions will be encouraging the Member States to consider the setting of the proposed minimum age. However, it is still the Member States that decide on the minimum age of the signatories. It seems that the right to participate

73 Art. 6(7) regulation 2019/788.

74 Art. 6(4) regulation 2019/788.

75 Ibidem. 
in the ECI will still be connected with the active voting right in the elections to the European Parliament.

Among the remaining changes one should point out the simplification of the requirements in the area of the signatories' data ${ }^{76}$. Moreover, the current regulation clearly points out that the signatories will be counted in their Member State of nationality ${ }^{77}$. The latter of the changes resulted from the occurrence of difficulties with counting signatures of persons living outside their country of nationality.

\subsection{European Citizens' Initiative as an instrument of e-democracy}

The leading trend in the area of democratization of the European Union is the use of the Internet and electronic means of communication at a distance for promoting debate and maintaining contact with the institutions of the European Union. Already before, the ECI had its own complex website and the primary regulation allowed for distant collection of declarations of support. Nevertheless, in so far as the votes could have been collected online, it was the ECI organizing committee that was responsible for the building of the system. Indeed, the reform actually strengthened the system by imposing on the EC the obligation to build its own central online system facilitating the collection of statements of support ${ }^{78}$. The use of a central online collection system is not compulsory though ${ }^{79}$. The organizers of the initiative retain the right to use other systems, which currently makes it possible to make use of the fast-developing online collection systems providing an opportunity to take part in voting.

In the area of promotion and assistance to the potential organizers of the ECI, the reform strengthened the obligation of the European Commission within the scope of its function to provide information and promotion $^{80}$ and it was especially obliged to run an online collaborative

76 Personal data regarding nationality, place of birth, place of permanent residence is no longer collected; instead a personal identification number or an ID number are required.

77 Art. 3(2) regulation 2019/788.

78 Art. 10 regulation 2019/788.

79 Art. 11 regulation 2019/788.

80 Art. 4 regulation 2019/788. 
platform ${ }^{81}$. Next to the system for "collecting votes" and the collaborative platform, the EC was obliged to make an online register for the European Citizens' Initiative available. The register consists of a publically available internet website providing comprehensive information on the European Citizens' Initiative in general, as well as up-to-date information on individual initiatives, their status and the declared sources of support and funding on the basis of the information submitted by the group of organizers. The general purpose of the register is to raise awareness and ensure transparency on all the initiatives. In the opinion of the EC, the register should allow the groups of organizers to manage their initiative throughout the procedure.

The present Regulation also clarifies and regulates the issue of email addresses for sending current information on the ECI, both by the EC and the group of organizers ${ }^{82}$. The collection of email addresses is optional and requires the explicit consent of the signatories. Email addresses should not be collected as part of the statements of support forms and potential signatories should be informed that their right to support an initiative is not conditional on giving their consent to collecting their email addresses.

\section{THE STRENGTHENING OF THE PRINCIPLE OF SUBSIDIARITY AND MULTI-LEVEL GOVERNANCE}

Undoubtedly, a significant change is that the assessment of the ECI is carried out by a broader number of institutions and bodies of the Union $^{83}$. At present, the European Commission is obliged to publish without delay a notice to that effect in the register and transmit the initiative to the European Parliament, the Council, the European Economic and Social Committee, the Committee of the Regions, that is, all the institutions which take part in the legislative procedure as legislators or provide advisory opinion. The saidbodies may then take part in the public hearing, which just like before is organized by the European Parliament. The group of

\footnotetext{
81 Art. 4(2) regulation 2019/788.

82 Art. 18 regulation 2019/788.

${ }_{83}$ Art. 14 regulation 2019/788.
} 
institutions and advisory bodies has been extended to include the national parliaments and civil society who all should be given the opportunity to attend the hearing ${ }^{84}$. The current Regulation endows the European Parliament with a special role in acting as a mediator between the organizers of the initiative and the European Commission, ensuring a balanced representation between the public and private interest ${ }^{85}$. Additionally, the EP has been equipped with the competence to assess both the political support for the initiative ${ }^{86}$, as well as the follow up actions of the $\mathrm{EC}^{87}$.

The rule of multi-level governance and indirectly the principle of subsidiarity is strengthened by the lengthening of time for the EC to prepare its response and currently the Commission should do it within six months and not within three months as was laid down in the previous Regulation. The lengthening of the time period for preparing its conclusions is intended to provide the EC with an opportunity to carry out extended consultations during its preparatory work with different institutions and advisory bodies.

\section{CONCLUSIONS}

The amendments introduced to the European Citizens' Initiative should contribute to the realization of the objectives of the Union's institutions. The matters concerning organizational frameworks should be easier for the groups of organizers and the ECI should receive wider recognition. The reform will have a positive impact on the Union's instruments of e-democracy ${ }^{88}$, will strengthen the principle of subsidiarity and will fit in well within the structure of multi-level governance. However, the changes do not directly affect the essence of the ECI as an effective tool for an indirect legislative initiative. The scale of success and effectiveness of the reform might be assessed when the objectives of the ECI are taken

84 Art. 14(2) regulation 2019/788.

85 Ibidem.

86 Art. 14(3) regulation 2019/788.

87 Art. 16 regulation 2019/788.

88 See: Eric Longo, The European Citizens' Initiative: Too Much Democracy for EU Policy?, German Law Journal 20(2019), 189. 
into consideration. In general, two major objectives could be identified, which are directly connected with each other. Indeed, what is significant is which of the objectives will be considered as superior and which as an instrumental one.

Firstly, the initiative can be viewed as a form of promotion of the Union itself, its aims and values, especially democracy. In such a case, the very signing of the statements of support under particular initiatives might already be considered as success. From such a perspective, what happens further with the initiative is not, indeed, important. If the above objective is given priority, then the reform might be assessed in very positive terms. Yet, the approach in which the promotion of the Union is a superior objective of the ECI may create an impression that the Union's institutions, especially the European Commission, whom the initiative is addressed to, do not treat the organizers of the initiative and its signatories as real partners and co-participants in the decision-making processes. In fact, this is contrary to the democratic principles which lie at the foundation of the Union itself. In the long run, it might discourage citizens from participating in the instrument, as it might create an impression that the EC does not treat this form of dialogue with society seriously.

Secondly, we might treat the citizens' initiative as an effective form of an indirect legislative initiative. The reform does not bring any significant alterations in this respect, even though the strengthening of the principle of subsidiarity and the lengthening of the time period for preparing a response on an ECI should be assessed positively. The latter changes may, but do not have to, contribute to an increase in the number of legislative proposals. It will be dependent on the internal dialogue between the competent entities. The reinforcing of the ECI's position as an indirect form of legislative initiative may be actually achieved without modifications to primary and secondary law. Indeed, it might be assumed that in the face of the EU's high political culture and its deep respect for the democratic principles, the European Commission should present legislative proposals that would realize the postulates of the ECI.

Nevertheless, it is highly probable that the future initiatives exceeding the required one million of statements of support will concern matters that will be ideologically or politically controversial or that will have considerable economic implications. Typically, such ideas have a greater chance to 
mobilize larger social groups. In fact, it might be observed that all the past initiatives heard by the Commission fall precisely within such categorization. Due to the weight of the subject matter, not all of them will enjoy the support of the Member States represented in the Council or the support of the majority of the members of the European Parliament. However, the submission of the citizens' initiative under legislative procedures definitively increases the transparency of the decision-making process. The European Commission may justify its refusal to prepare a legislative proposal by arguing that the European Parliament and the Council debated a given issue but the initiative was not received favourably. Still, such an approach is to the detriment of the transparency of the decision-making process. The special quality of the legislative procedure is that it can end in two ways. The submission of a legislative proposal may result in its adoption, but the proposal may also be rejected. However, the very procedure initiated by the ECI undoubtedly reinforces the democratic foundation of the Union.

\section{REFERENCES}

Athanasiadou Natassa, The European Citizens' Initiative: Lost in Admissibility?, Maastricht Journal of European and Comparative Law 2(2019), 252.

Barcz Jan, Inicjatywa obywatelska - aspekty prawne i instytucjonalne, Europejski Przegląd Sądowy 10(2011), 25.

Craig Paul, The Lisbon Treaty. Law, Politics, and Treaty Reform, UOP Oxford 2010, 77.

Cuesta-López Victor, A Preliminary Approach to the Regulation on European Citizens' Initiative from Comparative Constitutional Law, Bruges Political Research Papers / Cahiers de recherche politique de Bruges no 24 / February 2012, 8, https://www.coleurope.eu.

Głogowski Paweł, Andreas Maurer, The European Citizens' Initiative - Chances, Constraints and Limits, Political Science Series, Institute for Advanced Studies, Vienna 2013, 8.

Głogowski Paweł, European Citizens' Initiative in Central and Eastern European Countries - The Bumpy Road of Participatory Democracy in the EU, Studia Europejskie 1(2017), 190. 
Juncker Jean-Claude, A New Start for Europe: My Agenda for Jobs, Growth, Fairness and Democratic Change, https://ec.europa.eu/commission/presscorner/ detail/en/SPEECH_14_546.

Karatzia Anastasia, The European Citizens' Initiative and the EU Institutional Balance: On Realism and the Possibilities of Affecting EU Lawmaking, Common Market Law Review 1(2017), 177.

Kubin Tomasz, Znaczenie europejskiej inicjatywy obywatelskiej w kontekście deficytu demokracji w Unii Europejskiej, Politeja 54(2018), 117.

Longo Eric, The European Citizens' Initiative: Too Much Democracy for EU Policy?, German Law Journal 20(2019), 189.

Mendes Joana, Participation and the Role of Law after Lisbon: A Legal View on Article 11 TEU, Common Market Law Review 6(2011), 1849.

Organ James, Decommissioning Direct Democracy? A Critical Analysis of Commission Decision-Making on the Legal Admissibility of European Citizens Initiative Proposals, European Constitutional Law Review 10(2014), 422.

Petrescu Oana-Mariuca, The European Citizens' Initiative: A Useful Instrument for Society and for Citizens?, Revista Chilena de Derecho 3(2014), 966.

Śledzińska-Simon Anna, Obywatelstwo Unii Europejskiej jako demos, czyli fiasko demokratycznego telos?, In: Ochrona praw obywatelek i obywateli Unii Europejskiej. 20 lat - osiągnięcia i wyzwania na przyszłość, Adam Bodnar, Grażyna Baranowska, Aleksandra Gliszczyńska-Grabias, ed., Warszawa: Wolters Kluwer, 2015, 66.

Sadurski Wojciech, Democratic Legitimacy of the European Union: A Diagnosis and Some Modest Proposals, XXXII Polish Yearbook of International Law 2012, 33. 